\title{
Qualitative Analysis for Major in Speech Therapy and Auditory Rehabilitation and Working Experience in Clinical Field
}

\author{
Ji Youn Kim, Soo Bok Lee, Pyung Kon Thak \\ Department of Speech-Language Therapy and Aural Rehabilitation, Woosong University, Daejeon, Korea
}

\author{
Received: September 7, 2020 \\ Revised: September 28, 2020 \\ Accepted: October 4, 2020 \\ Correspondence: \\ Pyung Kon Thak, PhD \\ Department of Speech-Language \\ Therapy and Aural Rehabilitation, \\ Woosong University, \\ 171 Dongdaejeon-ro, Dong-gu, \\ Daejeon 34606, Korea \\ Tel: +82-42-630-9224 \\ Fax: +82-42-630-9229 \\ E-mail: imswan@daum.net
}

\begin{abstract}
The purpose of this study was to investigate the relationship between graduated students with major in speech therapy and auditory rehabilitation and their working experience in the clinical field by using a qualitative research method. After conducting in-depth interviews with seven graduates who majored in speech therapy and hearing rehabilitation, content analysis was performed. As a result of open coding the interview data, 2 dimensions, 8 core categories, 13 subcategories, and 69 concepts were derived. The 2 dimensions were divided into personal and social dimensions. Employment considerations, overall work, the relationship between majors and work, and the skills needed to perform work were discussed. This study explained the current status of work and job satisfaction of graduates from the department of speech therapy and audiology rehabilitation, a considerable relation between majors and jobs, and future development directions.
\end{abstract}

Key Words: Audiology rehabilitation, Clinical field experience, Job satisfaction, Qualitative research, Speech therapy.

\section{INTRODUCTION}

언어를 사용한 의사소통은 인간의 사회적 상호작용에서 매 우 필요하며, 청각은 언어와 밀접하게 연관되어 의사소통에 필 수적이다. 그리하여 의사소통에 문제가 있는 의사소통장애는 크게 언어치료와 청각재활이라는 두 개의 전문적 영역으로 나 눌 수 있다. 언어재활사는 생애 중 발생할 수 있는 의사소통문 제, 즉 언어와 말에 어려움이 있는 대상자들의 진단 및 재활을 담당하는 전문가를 말하며, 청능사는 난청인의 특성을 고려하 여 청각 기능의 평가와 재활을 담당하는 전문가를 말한다. 언 어치료와 청각재활 분야는 모두 의사소통에 어려움을 가진 사 람들을 대상으로 서비스를 제공하는 재활전문가이고 우리 사 회가 교육, 복지, 재활에 대한 관심이 높아짐에 따라 두 분야의 전문 영역은 점차 확대되고 있는 실정이다.

언어재활사와 청능사는 언어치료와 청각재활 관련 학위를 취득한 후 자격증 시험에 합격하면 의사소통장애를 가진 사람 들을 돕는 전문가로서 일하게 된다. 언어치료는 1988년 국내에 학과 과정이 개설되었고 1992년부터 민간자격증 형태로 운영되

(c) This is an Open Access article distributed under the terms of the Creative Commons Attribution Non-Commercial License (https://creativecommons.org/licenses/by-nc/4.0) which permits unrestricted non-commercial use, distribution, and reproduction in any medium, provided the original work is properly cited.
다가 2012년 장애인복지법에 근거하여 언어재활사 국가자격증 으로 전환되었다(Chang et al., 2018). 청능재활은 우리나라에 1997년 청각학 교육과정이 도입된 이래 1998년 청각학 석사과 정이 개설되었고, 2002년부터 청능사 시험을 실시하고 있다. 언 어재활사와 청능사 자격증을 취득하기 위해 현재 전국에 50 개 (Kim et al., 2018)의 언어치료 관련 학과가 있고 6개(2020년 7월 청각학교수협의회 등록 기준)의 청능재활 관련 학과가 운영 중 이다. 청능재활을 운영하는 학과들은 대부분 언어재활사와 청 능사를 동시에 준비하도록 학과를 운영하고 있다.

언어치료청각재활학과 졸업생들은 언어재활사로 종합병원, 개인병원, 복지관, 어린이집 등 보육시설, 특수학교, 교육청 등 의 교육기관, 다문화 가정지원센터, 노인 및 재활병원이나 시설 등에서 근무하거나 청능재활센터, 종합병원이나 개인병원, 연 구소, 클리닉, 보청기 제조사나 인공와우 제조사 등에서 청능 사로 일할 수 있게 된다. 언어치료와 청능재활은 전문화된 직종 으로 다양한 임상 현장에서 일할 기회가 주어지며, 임상 현장 의 여러 요소들이 직무 수행에 영향을 미칠 수 있다. 언어재활 사 국가자격증 도입 이후 국내에서 언어재활사의 직무에 관한 연구는 이루어지고 있으나, 청능사의 직무와 스트레스에 대한 연구는 거의 이루어지지 않았으며, 언어치료와 청능재활 두 개 의 전공을 이수하고 현장에 취업해 있는 언어재활사나 청능사 
의 직무가 무엇인지, 직무에 대한 만족도는 어떠한지, 어떤 요 소들이 직무에 영향을 주는지에 대한 연구는 전무한 상태이다. 언어재활사 직무에 관한 선행 연구들을 살펴보면, 언어치료학 과 졸업생이면서 경력 4년 이하의 초보 언어재활사들을 대상으 로 취업, 이직 현황과 직무만족도를 조사한 Chang \& Park(2012) 의 연구에서 졸업생들은 학교에서 배웠던 전공에 대한 이론적 인 지식과 임상현장의 실제가 달라서 어려움을 겪는다는 의견 이 가장 많았고, 치료 전반에 대해 언어재활사로서 스스로가 부족하다고 느껴서 직무 수행에 어려움이 많다고 하였다. 언어 재활사의 직무만족도는 근무기관, 경력이나 급여 등이 영향을 미치는 것으로 나타났다(Hwang et al., 2015). 언어재활사가 느 끼는 치료능력 부족과 직무만족도를 높이기 위해서는 양질의 자격증 유지를 위한 보수교육과 전문성을 높일 수 있는 장애영 역별 슈퍼비전 프로그램, 소규모 교육 개발이 필요하다(Kim \& Park, 2018). 미국의 경우 언어재활사와 청능사 모두 대체적으 로 그들의 직업에 만족하고 있으며 학력과 경력, 근무지, 급여 등에 따라 직무만족도에 차이를 보인다고 하였다(Kalkhoff \& Collins, 2012; Martin et al., 1997; Saccona \& Steiger, 2012). 청능사의 직무 스트레스에 관한 연구에 따르면, 시간에 쫓기는 업무(time demand)가 청능사들에게 가장 큰 스트레스로 작용 한다고 하였고, 근무기관이나 근무 경력, 청능사의 연령 등에 따라 청능사들이 느끼는 스트레스 정도는 다르다고 하였다 (Severn et al., 2012).

언어재활사나 청능사는 고도로 특화 및 전문화된 직종으로 각 직종에서 근무하고 있는 언어재활사와 청능사의 일반적 사 항과 직무 특성을 살펴보고, 직무 만족 수준 및 전공과 직무의 관련성, 직무의 발전 방향 등을 파악하여 언어치료와 청능재활 의 교육과정에 발전적인 제안을 하는 것이 필요하다. 졸업생들 의 임상 현장 경험에 대한 직무 특성을 파악하고 전공과의 관련 성, 직무에 어려움을 미치는 요인들을 파악하는 것은 매우 의 미 있는 일이다. 그러므로 졸업 후 전공 업무 환경의 적응에 대 한 실증적이고 심층적인 면담은 언어치료청각재활학과 졸업생 들의 사회생활 적응에 대한 이해를 돕고 전공 업무 및 대학생활
만족도를 높일 수 있는 방안을 모색하는 데 도움이 될 것이다.

본 연구에서는 언어치료청각재활학과를 졸업하고 현장에서 일하고 있는 언어재활사와 청능사와의 면담을 통해 현재 맡고 있는 업무 현황과 직업의 만족도, 업무와 전공 관련성 여부, 언 어치료와 청능재활의 각 분야에서의 미래 전망과 발전 방향에 대해 질적 연구방법으로 분석하고자 한다.

\section{CASE REPORT}

\section{연구 대상}

본 연구참여자들은 언어치료청각재활학과를 졸업하고 임상 경험이 3년 이상인 7명의 언어치료사 및 청능사들이다. 자료를 수집하고 동시에 분석을 실시하여 더 이상의 추가적인 데이터 수집이 필요하지 않은 포화(saturation)상태에 이르렀다고 판단 이 되어 최종 7 명을 연구 참여자로 선정을 하였다. 이들은 심층 면담 당시 언어치료 및 청각 임상 현장에서 모두 근무를 하고 있었다. 연구자들은 연구참여자 선정 전 먼저 선정 기준을 만 들었다. 첫째, 언어치료 및 청각재활을 전공한 경우, 둘째, 임상 현장의 실태를 충분히 파악할 수 있는 3년 이상의 경력을 가지 고 있는 경우로 하였다. 연구자들은 이러한 선정 기준을 만든 후 본교 졸업생들에게 연구의 목적과 취지를 설명한 후 연구 참여에 동의한 졸업생들을 대상으로 연구참여자들을 구성하였 다. 연구참여자 선정 기간은 2020년 5월부터 6월까지 총 2개월이 소요되었다. 연구참여자들의 인구사회학적 특성과 임상 현장 특성은 Table 1과 같다.

\section{자료 수집}

연구자들은 연구참여자들과 질문지(Appendix)를 토대로 심 층 면담을 수행하여 분석 자료를 수집하였다. 연구참여자들은 졸업 후 임상 현장에서 일을 하면서 업무 역량, 전공 관련성, 업 무 만족도, 미래 발전 방향과 관련된 경험을 구술했다. 심층 면 담은 연구참여자들의 사업장, 커피숍, 주 저자 연구실 등 연구참 여자들이 편안함을 느낄 수 있는 곳에서 수행하였다. 연구자들

Table 1. Demographic information of seven participants

\begin{tabular}{llccclcl}
\hline No & Sex & $\begin{array}{c}\text { Age } \\
\text { (years) }\end{array}$ & $\begin{array}{c}\text { Occupational } \\
\text { experience (years) }\end{array}$ & $\begin{array}{c}\text { Graduation } \\
\text { year }\end{array}$ & Type of certificate & $\begin{array}{c}\text { Dual } \\
\text { major }\end{array}$ & Type of field \\
\hline S1 & Male & 27 & 3.0 & 2016 & Audiologist & X & Cochlear implant company \\
S2 & Female & 29 & 3.5 & 2014 & Audiologist & X & Hearing aid company \\
S3 & Male & 27 & 3.2 & 2016 & Audiologist & O & Hearing aid company \\
S4 & Female & 26 & 4.0 & 2015 & Speech language pathologist & O & Welfare center \\
S5 & Male & 33 & 8.0 & 2010 & Speech language pathologist & X & Private center \\
S6 & Female & 26 & 4.0 & 2015 & Audiologist & O & Nonprofit social enterprise \\
S7 & Female & 31 & 6.0 & 2012 & Speech language pathologist & X & Hospital \\
\hline
\end{tabular}


은 포화의 원칙을 달성하기 위하여 7 명의 연구참여자들을 확보 하는 한편 연구참여자들과 1 회기에 걸친 심층 면담을 실시했다. 1 인당 평균 인터뷰 시간은 한 회기 당 약 60 분 정도 소요되었다.

\section{자료 분석}

자료 분석은 Krippendorff(2003)가 제안한 내용분석 절차에 따라 분석하였다. 첫 단계는 텍스트 전체에 대한 연구자의 이 해과정으로 연구자들은 심층면담 기록을 반복하여 읽으면서 이들의 경험이 언어치료 청각재활학과 졸업생의 경험으로서 적 합한가를 검토했다. 두 번째 단계는 의미 있는 진술(significant statement)을 찾으려고 노력하였다. 연구자는 참여자들의 구술 한 내용을 문장으로 만들었고 이 문장이나 어구들 중에서 본 연구와 관련된 의미 있는 진술들을 발견하여 의미를 구성했다. 다음 단계는 범주화단계이다. 연구자는 의미진술을 개념화 한 후 이 개념들 중 서로 관계있거나 유사한 것들을 결집하여 범 주화하였다. 마지막 단계는 이러한 범주를 개인척 차원, 사회적 차원으로 나누어 범주를 재배열했다.

\section{연구의 신뢰성 및 타당도 확보}

연구의 신뢰성과 타당성을 확보하기 위하여 면담 전 질문 내용, 연구 절차, 주제 도출 내용 등에 대하여 연구 주제에 익숙하고 10 년 이상의 언어치료 청각재활 임상 현장에서 근무한 경력이 있으 며 또한 질적 연구 수행 경험이 있는 전문가에게 의뢰하여 점검 을 받았다. 코딩과 주제 도출 과정이 적절하게 이루어졌는지 확 인하기 위하여 연구참여자에게 추후 연락하여 도출된 주제와 의 미 범주가 적절한지, 본인의 진술 의도와 부합하는지 확인하여 타당도를 확보하였다. 재차 확인하는 절차에서 추가로 진술된 내 용은 다시 면담 내용에 포함하여 전사하고 분석하는 과정을 거 쳤다. 전사한 자료는 3 인의 연구자가 모여 비슷한 개념으로 1 차 범주화하였고 하위범주를 개념화하는 작업을 수행하였다. 그리 고 범주화된 항목들을 분석표로 만들었고 개념, 하위범주, 핵심 범주, 차원 구성요소에 대해 4차례에 걸쳐 내용 타당도를 점검하 였다. 1차, 2차, 3차 점검에서는 하위범주들이 같은 의미의 범주 로 구성이 가능한지 점검하였으며, 4차 점검에서는 구성된 아이 템을 대표할 수 있는 차원에 대한 사항을 점검하였다.

\section{연구 결과}

원 자료를 개방 코딩한 결과, 2 개의 차원과 8 개의 핵심범주, 13 개의 하위범주, 69 개의 개념이 도출되었다. 핵심범주 결과는 Table 2 와 같다.
Table 2. Core categories based on dimensions

\begin{tabular}{ll}
\hline \multicolumn{1}{c}{ Dimensions } & \multicolumn{1}{c}{ Categories } \\
\hline Individual dimension & Seeking for a job choice \\
& Comprehensive job performance \\
& Need for challenge \\
& Development potential \\
Social dimension & High relationship between major and job \\
& Need for social skill \\
& Regret for dual major \\
& Importance of mutual communication \\
\hline
\end{tabular}

\section{개인적 차원}

직업 선택을 위한 모색

연구참여자들은 졸업 후 직장을 선택할 때 전공과 상관없이 연봉 및 회사 복지를 포함한 경제적인 면을 고려하였다. 연구참 여자 $2,4,6,7$ 은 연봉을 고려하여 직장을 선택하였고 또한 연 구참여자 2는 회사 복지도 고려하였다. 그리고 연구참여자 7은 치료 케이스에 따라 달라지는 언어치료 센터와 다르게 고정적 인 연봉을 받을 수 있는 병원을 선택하기도 하였다.

"저는 직장을 선택할 때 연봉을 우선시 했던 것 같아요." (연 구참여자 2)

"센터에서는 기복이 있었는데 병원에서는 그런 게 없기 때문 에 좀 안정적인 것이 커서 병원으로 가고 싶었던 것 같아요." (연 구참여자 7)

또한 연구참여자들은 근무환경도 고려하여 직장을 선택한다 고 하였다. 연구참여자 2,5 는 회사 분위기가 좋다는 지인의 추 천으로 직장을 결정하였고, 연구참여자 6은 이직할 때 회사 이 름을 많이 보았고, 연구참여자 4는 치료를 많이 해서 치료 경력 을 쌓기보다는 행정 업무도 겸해서 할 수 있기를 원해서 사설 언어치료 센터보다 치료가 많지 않은 복지관을 선택하였으며 연구참여자 7은 규칙적이고 정해진 직장생활을 할 수 있는 병 원을 선택하였다.

"복지관에서 일하면 치료가 센터보다는 많지 않잖아요. 그래 서 선택했어요." (연구참여자 4)

"어쨌든 전반적으로 봤을 때 (사설 언어치료)센터는 모든 게 상황에 따라 모든 것이 바뀌는데 병원에서는 그런게 없기 때문 에 좀 안정적인 것이 좋아서 병원으로 가고 싶었던 것 같아요." (연구참여자 7) 
이외에도 연구참여자들은 직장을 선택할 때 발전 가능성도 고려한 것으로 나타났다. 연구참여자 3 은 미래의 전망을 보고, 많이 배우고 고객을 직접 대할 수 있는 점이 좋아서 보청기 회 사를 선택하였으며 연구참여자 1 은 보청기 회사는 상업적인 것 같아서 인공와우 회사를 선택하기도 하였다.

"저는 일단은 좀 전망적인 부분을, 미래를 많이 봤던 것 같아 요." (연구참여자 3)

"인공와우는 조금 덜 상업적이고 더 내가 그 쪽 분야에서 일 했을 때 조금 더 유니크하겠다 이런 느낌이 들어서 보청기 말고 인공와우 쪽을 선택했어요." (연구참여자 1)

연구참여자들이 직장을 선택할 때 경제적인 면, 근무 환경, 발전 가능성을 고려하여 직장을 선택한 연구참여자들의 경험 을 “직업선택을 위한 모색”이라는 범주로 명명하였다.

\section{포괄적 업무 수행}

연구참여자들 대부분은 졸업 후 전공과 관련된 업무를 수행 하고 있었다. 주로 청각재활을 전공한 연구참여자들은 보청기 회사에서 영업과 교육을 담당하고 있었고(연구참여자 2,3 ), 또 한 인공와우 회사에서 인공와우 매핑, 상담 업무를 담당하고 있었다(연구참여자 1 ).

"코클리어 제품을 사용하시게끔 영업을 하고 있고요. 그리고 추가적으로 바하(BAHA)나 인공와우 매핑 업무도 같이 하고 있 어요." (연구참여자 1)

반면 언어치료를 전공한 연구참여자들은 복지관에서 언어치 료를 하고 있었고(연구참여자 4), 또한 대학병원에서 음성장애 나 청각장애 대상자들을 평가하고 치료하는 업무를 하고 있었 다(연구참여자 7). 그리고 언어치료 센터를 운영하면서 언어치 료를 하고 부모상담 및 부모 교육을 하고 있었다(연구참여자 5).

"제 업무는 병원에서 이비인후과 소속 언어재활사로 일을 하 고 있는데 주로 음성장애나 청각장애 환자들을 평가하고 치료 하는 업무를 하고 있습니다." (연구참여자 7)"

그러나 일부 연구참여자들은 센터 및 병원에서 전공 이외의 부수적인 업무도 수행하고 있었다. 연구참여자 6은 인공와우 회 사에서 근무하다가 일을 그만둔 후 청각장애인 생애지원센터에 서 청각장애인들이 도움이 필요할 때 상담을 해주거나 회사 마 케팅 업무를 수행하고 있었으며, 연구참여자 4는 청각장애 복지 관에서 언어치료 이외에도 복지 업무를 담당하고 있었다.
"어떻게 하면 회사에서 조금 더 많은 수익을 얻어서 더 많이 사회에 공헌을 할지 고민도 계속하고..." (연구참여자 6)

"복지관에서 일하는 것은 아무래도 언어치료 센터보다는 복 지적인 측면이 더 강하고요." (연구참여자 4)

이와 같이 언어치료청각재활을 전공한 학생들은 현장에서 전공 업무 수행을 하고 또한 전공 업무 이외의 부수적인 업무 도 수행하고 있는 이들의 경험을 “포괄적인 업무 수행”이라는 범주로 명명하였다.

\section{도전의 필요성}

졸업 후 직장을 갖게 된 연구참여자들은 회사 적응의 어려 움을 겪고 있었다. 연구참여자 6은 수익을 창출해야 하는 회사 분위기에 적응하는 데 어려움을 경험하였고 스스로 새로운 일 을 만들어 내는 것에 대한 부담감을 갖고 있었다. 연구참여자 2 는 본인의 잘못도 아닌데 회사를 대신해서 소비자나 보청기 센 터 원장들에게 사과해야 하는 것을 받아들이는 것에 대해 어 려움을 경험하였다.

“보청기를 납품했는데 뭐 작동이 안 된다던가, 그런데 센터 원장님들 입장에서는 이제 너무 큰 손해로 다가오니까 화를 낼 수밖에 없는데 그게 어떻게 보면 저 혼자만의 실수는 아닌데 회 사를 대신해서 사과를 드리고 또 해야 된다는 게 어려움은 있었 죠." (연구참여자 2)

또한 연구참여자들은 동료들 및 치료 대상자들과 관계 맺는 것을 어려워하기도 하였다. 연구참여자 3 은 처음 입사할 때 동 료들과 생각의 차이가 깊어서 회사에 적응하는 데 어려움을 겪 었고, 연구참여자 6은 본인이 상담해주는 장애 당사자들이 오 해를 자주 해서 적응하는 데 어려움을 겪었고 또한 청각장애를 가진 동료들과 일하면서 정상인들과 다른 모습을 보이는 청각 장애 동료들과 적응하는 데 어려움을 겪었다. 또한 연구참여자 4는 치료가 맘에 들지 않는다고 언어재활사를 바꾸어 달라고 요구하는 부모들 때문에 어려움을 겪었다. 그리고 연구참여자 5 는 부모 상담하는 어려움을 경험하였다.

"선생님이 2 명이니까 제 수업을 듣다가 마음에 안 들면 저 선 생님으로 바꿔주세요 했을 때 저는 그 말로 인해 상처를 받는 거예요. 아! 내 치료가 얼마나 마음에 안 들어서 가는 거지라고 고민하게 돼죠" (연구참여자 4)

이와 같이 연구참여자들이 회사에 적응하는 어려움을 경험 하고 직장 동료들 및 치료 대상자들과 관계 맺는 어려움을 경 
험한 연구참여자들의 경험을 “도전의 필요성”이라는 범주로 명 명하였다.

발전 가능성

연구참여자들은 졸업 후 환자들에게 더 좋은 치료 서비스를 제공하기 위해 본인이 성장해야 한다는 필요성을 느끼고 있었 다. 연구참여자 3 은 계속 공부를 할 필요성을 느끼고 또한 새 로운 케이스가 나왔을 때 새로운 치료 방법에 대한 고민을 하 고 있었다. 또한 연구참여자 7은 병원에서 같이 일하고 있는 의 사들과 협력을 잘 하기 위해 스스로 더 많은 공부를 하고 있었 으며, 연구참여자 4는 본인이 맡은 환자들에 대한 치료 접근 방 법을 몰라서 책을 보거나 다른 전문가들에게 도움을 구하였지 만 해답을 구하지 못하였을 때 본인 스스로 더 성장해야 한다 는 필요성을 절실히 느꼈었다.

"어떻게 접근해야 할지 모르겠고, 도저히 책에 나오는 걸 다 해 보았는데도 안 될 때 어디다가 물어봐야 되지 하면서 고민하 게 되었어요." (연구참여자 4)

연구참여자들은 현장에서 일하면서 위와 같은 성장의 필요 성을 느끼기도 하지만 경력이 쌓여 가면서 연구참여자 5 는 교 재 개발을 하거나 대학 강의를 하게 되었고, 연구참여자 3 은 직 장 동료들과 잘 어울리며 일하게 된 것을 본인에게 주어진 기회 라 생각하면서 회사에 잘 적응하고 있었다.

"그러다보니까 그걸로 뭔가 하고 싶은 사업이나 뭐 교재개발 이나 이런 것들도 좀 할 수 있고, 강의 자리도 대학교뿐만 아니 라 여기저기에서 해달라고 하고" (연구참여자 5)

또한 연구참여자들은 자신의 업무에 만족해하며 일하고 있 었다. 연구참여자 4는 업무량이 많지 않고 서류 작업이 본인의 적성에 맞아서 현 업무에 만족해하고 있었고, 연구참여자 1 은 소리를 듣지 못하던 90세 할머니가 본인의 도움으로 인해 소리 를 듣고 우는 모습을 보면서 자신의 업무에 무척 만족해하고 있었다.

"90세 넘으신 할머니가 계셨어요. 인공와우 첫 착용을 할 때 이제 소리를 못 듣다가 들으시고 바로 문장 수준까지 대화를 하 셨어요. ‥(중략) 그런걸 보면서 내가 이들한테 행복을 드릴 수 있는 일을 한다는 게 좀 감격적이고 보람 있었던 것 같아요." (연 구참여자 1)

이와 같이 새로운 환자들을 만나게 될 때 본인의 부족함을
깨닫고 성장의 필요성을 느끼지만 경력이 쌓여 가면서 더 많은 기회를 얻게 되고 직장 동료들과 잘 어울리는 기회를 갖게 되면 서 본인의 현 업무에 대해 만족을 느끼는 연구참여자들의 경험 을 “발전 가능성”이라는 범주로 명명하였다.

사회적 차원

전공과 업무의 높은 연관성

연구참여자들은 복수전공을 한 것이 부모들을 상담할 때(연 구참여자 4), 그리고 청각장애 아동을 치료하는 언어재활사들 이 복수전공 한 본인에게 질문할 때, 복수전공한 것이 많은 도 움이 되었다고 보고하였다(연구참여자 5). 또한 청각 전공자들 은 보청기 적합 상담할 때(연구참여자 2) 그리고 언어치료 전공 한 연구참여자들은 임상에서 사용할 교재교구 개발할 때(연구 참여자 5) 전공이 자신의 업무와 연관성이 매우 높다고 인식하 고 있었다. 특히 연구참여자들은 임상에서 치료할 때 대학에서 배운 기초 이론의 소중함을 소중하게 생각하고 있었다. 인공와 우 회사에서 근무하고 있는 연구참여자 1 은 학부에서 배운 인 공와우, 청각해부생리, 보청기 수업 등이 많은 도움이 되었다고 보고하였고, 연구참여자 7은 현장에서 치료할 때 학교에서 배 운 이론들이 많은 도움이 되었다고 하였으며, 연구참여자 5 는 아동의 조음문제를 치료할 때 이론의 소중함을 깨달았다고 보 고하였다.

"입사 초반에는 인공와우를 왜 이렇게 자세히 배웠지 했는데 환자들을 계속 만나서 도움을 드리다보니까 학부 때 배웠던 인 공와우 지식이 많은 도움이 되었어요" (연구참여자 1)

특히 연구참여자들은 현장에서 전공 만족도가 매우 높았다. 의사들과 일을 할 때(연구참여자 3 ), 전공이 다른 동료들과 일 을 할 때(연구참여자 4), 그리고 부모들과 상담을 해야 하는 현 장에서 언어치료청각재활 전공에 대한 만족도가 매우 높았다 (연구참여자 4).

"청각해부생리와 보청기를 접목해서 설명 드리면 원장님들이 이해하시고 바로 적용하시는 것 같아요. 그런 부분이 많은 도움 이 되었어요" (연구참여자 3)

이와 같이 연구참여자들이 전공의 소중함을 알고, 학교에서 배운 기초 이론의 소중함을 깨닫고 이를 현장에서 적용하는 것 에 매우 만족스럽게 생각하는 연구참여자들의 경험을 '전공과 업무의 높은 연관성이라고 범주화하였다. 
사회적 기술의 필요성

연구참여자들은 임상 현장에 나가기 전 상담 능력의 필요성 을 절실히 느끼고 있었다. 연구참여자 6은 후배들이 임상 현장 에 나가기 전에 상담하는 것을 많이 보고 나갔으면 좋겠다고 하였고, 연구참여자 5는 상담 기술 전문가들이나 교수님들이 직접 지도해 주었으면 하는 아쉬움을 보고하였고, 연구참여자 7 은 부모와 상담할 때 상담 능력이 크게 필요하다고 보고하였 다. 이는 모든 연구참여자들이 임상현장에서 환자를 만나거나, 의사나 다른 동료들을 만날 때 상담 능력이 필요함을 절실히 느끼고 있었다.

"상담은 좀 더 많이 후배들이 필드 나가기 전에 좀 많이 봤으 면 좋겠어요" (연구참여자 6)

또한 연구참여자들은 임상 현장에서 상담 능력 못지않게 대 화 능력이 중요하다고 느끼고 있었다. 연구참여자 6 은 농인들과 대화를 잘하지 못하는 동료가 안타깝다고 보고하였고, 연구참 여자 1 은 의사들과 대화를 할 때 주제를 정해서 분위기를 부드 럽게 만들면서 대화를 끌어가는 능력이 중요하다고 하였다.

"뭔가 토픽을 정하는 그런 능력들도 필요하고 센스있게 대화 를 이어가는 것도 중요한 것 같아요." (연구참여자 1)

이처럼 임상 현장에서 일을 할 때 상담 능력과 대화 능력이 필요하다고 느낀 연구참여자들의 경험을 사회적 기술의 필요 성'으로 범주화 하였다.

복수전공에 대한 아쉬움

연구참여자들은 임상 현장에서 일을 하면서 학부에서 좀 더 많은 현장 실무 경험을 쌓는 것이 필요하다고 인식하고 있었다. 연구참여자 5 는 학기 중에 선배들이 와서 자신들이 느낀 임상 경험을 사례를 들어 설명해 주는 시간이 있었으면 좋겠다고 하 였고, 연구참여자 6 은 기기로만 배우지 않고 실제로 체험해 보 면서 경험해 볼 수 있는 기회가 제공되었으면 좋겠다고 하였고, 연구참여자 2는 인턴 제도가 활성화 되었으면 좋겠다고 하였다.

"제가 지금 회사에 있다 보니까 견학도 많이 오던데 좀 더 많 이 기회가 주어지면 좋을 것 같고, 인턴제도 이런 게 좀 활성화 되면 좋겠어요" (연구참여자 2)

또한 복수전공을 하지 않은 연구참여자들은 복수전공에 대 한 아쉬움을 갖고 있었다. 연구참여자 1 은 중복 장애를 가진 인공와우 아동들을 매핑할 때 복수전공을 하지 않은 것에 대
한 아쉬움을 보고하였고, 연구참여자 3 은 취업을 할 때나 환자 를 직접 대할 때 복수전공을 하지 않은 것에 대한 후회를 하였 다. 또한 청각 현장에서 근무하는 연구참여자 6 은 언어 전공을 하는 후배들을 부러워하였다.

“지금 후배들이 부러운 게 언어전공을 저도 좀 했으면 좋았을 거 같다라는 생각을 많이 해요." (연구참여자 6)

이처럼 연구참여자들은 임상 현장에서 본인들이 어려움을 만날 때 복수전공을 하지 않은 것에 대한 후회를 하고 있는 연 구참여자들의 경험을 '복수전공에 대한 아쉬움’으로 범주화하 였다.

교류의 소중함 인식

연구참여자 3 은 현장에서 사용할 수 있는 검사를 위한 워크 샵의 필요성을 느겼고, 연구참여자 7은 아동들의 성장이 빨라 서 학교에서 배운 이론만으로는 임상 현장에서 사용하는 데 한 계를 느껴서 이에 대한 지식을 습득할 수 있는 워크샵의 필요 성을 느꼈고, 연구참여자 1 은 해외 학회에 가서 해외 전문가들 과도 교류하기를 원하였다.

"학회도 마찬가지구요. 해외 학회도 기회가 되면 꼭 가서 해 외 전문가와도 교류하고 싶어요." (연구참여자 1)

또한 연구참여자들은 졸업 후 학과와의 지속적인 교류를 원 하고 있었다. 연구참여자 3 은 학과의 정체성을 확립하는 것이 경쟁력을 갖추는 것이라고 생각하였고, 연구참여자 2 는 학과에 서 좋은 후배들을 양성해서 임상 현장으로 내보내주기를 원하 였고, 연구참여자 6은 취업을 하기 위해서는 전공 지식도 중요 하지만 학생들의 성격에 따라 진로를 지도해 주는 것이 중요하 다고 하였다. 이외에도 연구참여자 5 는 상담에 대한 훈련을 선 배로부터 받기를 원했고, 연구참여자 3 은 졸업생들과 재학생과 의 유대관계가 중요하다고 하였으며, 연구참여자 1 은 상담 진로 를 위해 후배들이 본인에게 연락하면 자신의 노하우를 전수해 주고 싶다고 하였다.

"선배들이 와서 상담에 대한 거를 케이스별로 설명해 주면 좋 을 것 같아요" (연구참여자 5)

이처럼 연구참여자들은 졸업 후 다양한 전문가, 학과, 동문 들과 교류하는 것이 중요함을 인식하고 있는 경험을 '교류의 소 중함 인식'으로 범주화하였다. 


\section{DISCUSSIONS}

본 연구는 현장에서 일하고 있는 언어치료청각재활학과 졸 업생을 대상으로 면담을 진행하고 내용분석을 통해 전공과 임 상 현장 경험에 대해 구체적으로 알아보고자 하였다. 질문의 형 태는 개방형 질문에 대한 동일 개념끼리 범주화하고 이를 대표 하는 상위범주 개념을 명명하였다. 면담 결과를 개인적 차원과 사회적 차원으로 나누어 개인적 차원에서는 직장을 위한 선택, 업무 수행시 어려움, 도전의 필요성, 발전 가능성으로 분류하 고, 사회적 차원에서 전공과 업무의 연관성이나 상호작용 기술 등 현장 업무 수행에 필요한 능력 등으로 분석해보았다. 그 결 과를 구체적으로 살펴보면 다음과 같다.

개인적 차원에서 살펴보면 연구대상자들이 직장을 선택할 때 언어치료 전공이나 청각재활 전공 졸업생 모두 직장이 안정 적인지, 미래 발전 가능성이 있는지에 대해 가장 많이 고려한다 고 답하였다. 이는 언어치료 전공 졸업생의 경우 언어재활사들 의 조기 이직의 원인이 근무환경이나 급여 때문이라는 선행 연 구 결과와도 일치한다(Chang \& Park, 2012). 그밖에 급여나 직 장 내 분위기, 복지, 승진 여부에 대해서도 영향을 미치기는 하 지만 자신의 성향과 안정성을 가장 중시하는 것으로 나타났다. 현대 사회가 미래에 대한 불안감이 높다보니 더더욱 안정적으 로 계속 다닐 수 있는 직장을 선호하는 것으로 보인다. Chang \& Park(2012)과 Lee \& Hwang(2013) 등의 연구에서도 근무 기관에 따른 언어재활사의 만족도에서는 차이가 없었으나 정규 직의 만족도가 높다고 하였다. 특히, 언어치료 전공 졸업생들은 주로 사설 언어치료센터에서 비정규직으로 시간제 근무를 하 면서 비율제 급여를 받는 경우가 많아 직업의 안정성을 우선으 로 생각했을 가능성이 높다. 우리나라도 미국의 경우처럼 많은 언어재활사와 청능사들이 학교에서 근무하는 공적 서비스 지 원의 차원에서 언어치료나 청각재활 서비스를 제공할 필요가 있으며 이를 위해 고용형태, 근무형태, 및 급여형태 등에 대한 안정성을 보장할 수 있는 방향의 직제 개발이 필요하다(Chang et el., 2018; Jang et al., 2007)고 하겠다.

언어치료청각재활학과 졸업생들이 현재 하고 있는 업무는 대부분 학과전공과 관련된 업무였으며 세부전공별로 전공 업 무를 나누어보면, 언어치료 전공 졸업생들은 복지관, 종합병원, 센터 등에서 언어평가 및 치료 업무를 비롯하여 부모 상담과 부모 교육 등을 수행하고 있었다. 청각재활 전공 졸업생들은 보 청기 센터, 인공와우 회사, 사회적 기업 등에서 보청기나 인공 와우 관련 영업을 하면서 청각장애 대상자에게 재활 관련 서비 스를 제공하고 있었다. 그리고 주요 업무 외에도 마케팅 업무나 컨설팅, 서비스 대상자의 생애 변화와 관련된 복지 업무 등 전 공과 관련된 부수적인 업무도 같이 수행한다고 하였다. 졸업생
대부분은 자신이 하고 있는 일에 만족을 느낀다고 하였지만 근 무기관에 따라, 부과되는 업무에 따라 직무에 대한 만족이나 불만족의 원인이 되기도 하였다. 언어치료 전공 졸업생들은 학 교에서 이론으로 배우고 실습을 했지만 현장에서 학교에서 미 처 다루지 못했던 더 많은 장애를 접하게 되니 언어치료 업무 자체에 대한 능력과 관련된 어려움이 주를 이루었으며 또한 다 른 언어재활사와 비교 당할 때 스트레스와 부담을 더 받게 된 다고 하였다. 청각재활 전공 졸업생들은 같은 직종에 근무하는 동료나 상사와의 관계에서 어려움을 보였고, 센터나 회사에서 영업 서비스를 제공함으로써 거기서 비롯한 직무 스트레스가 많은 것으로 나타났다. 또한 영업 방면으로도 일을 하면서 경제 적인 측면에서 회사의 이익 증대나 고객의 경제적인 손실 등이 스트레스로 작용한다고 하였다. 선행 연구들에서도 언어재활 사는 치료 능력과 같은 직무 자체, 행정적인 서류 업무, 상담 기 술 부족에서 스트레스를 많이 받는다고 하였고(Hwang et al., 2015; Kim \& Park, 2018; Park et al., 2016), 청능사는 업무와 관련된 시간 부족, 대상자에 대한 책무나 대상자와의 상담 등이 스트레스로 작용한다고 하였다(Brännström et al., 2016; Severn et al., 2012).

언어재활사들의 직무만족에 관한 선행연구 결과는 전문성 향상, 급여, 승진 등이 긍정적인 영향을 미치는 요인으로 나타 났다(Chang \& Park, 2012; Lee \& Hwang, 2013). 이에 반해 스트레스는 직무만족을 낮추는 것으로 나타났으며, 직무만족의 하위 영역을 업무, 보수 및 승진, 상사 및 동료, 기관으로 살펴본 결과 업무만족이 가장 높은 것으로 나타났고 보수 및 승진에 대 한 만족도가 가장 낮게 나타났다(Lee \& Hwang, 2013). 언어재 활사와 청능사를 대상으로 한 선행연구 결과처럼 본 연구의 참 여자들도 전문적인 영역을 요구하는 직종이다 보니 치료 능력이 나 전문성이 부족하다고 느끼면서 직무만족도가 저하되고 역할 스트레스를 받는 것으로 나타났다(Han \& Lee, 2015).

사회적 차원의 결과를 토대로 논의해보면, 언어치료청각재활 학과 졸업생들이 느끼는 전공과 업무의 연관성이 매우 높았다. 아직 경력이 적은 전문가로서 어려움을 갖고 있긴 하지만 업무 내용이 학교에서 배운 전공들과 연계되면서 기초 이론뿐만 아 니라 전공 심화에서 다륐던 전공 지식이 업무에 많은 도움이 되며, 모두가 실제 업무에서 필요한 내용이라고 하였다. 언어치 료와 청각재활 두 가지 전공을 모두 이수한 졸업생의 경우 현 재 업무를 수행하는 데 한 가지를 전공한 다른 전문가에 비해 능력을 더 인정받을 수 있다는 의견이 많았다. 학부제로 언어치 료와 청각재활의 두 개의 전공 중 하나를 택해서 자격증을 취 득했거나 타 전공을 복수 전공했던 졸업생들의 경우 언어치료 와 청각재활을 같이 전공했다면 현재 하고 있는 업무에 더 많 은 도움이 되었을 것이라고 하면서 두 전공을 모두 택하지 못 
했던 것에 대한 아쉬움을 나타냈다. 현재 우리나라에서 청각재 활을 공부할 수 있는 대학 교육과정이 많지 않고 몇 개의 대학 을 제외하고는 대부분이 언어치료와 청각재활 두 개의 전공을 따로 선택해서 공부하도록 되어 있다. 의사소통이라는 테두리 안에서 언어치료와 청각재활이 서로 밀접한 관련이 되어있음 에도 불구하고 두 전공 모두 공부하기가 어렵고 교과과정 운영 이 쉽지 않다는 현실을 고려하면 당연한 결과이다. 그러나 실제 현장에 나가서 일을 하다 보면 청능사가 주로 다루는 청각장애 인들이 의사소통에 문제가 있는 경우가 대부분이고 언어재활 사가 청각장애를 가진 대상자를 평가 및 치료해야 하는 경우가 많으므로 이 두 분야를 모두 공부했을 때의 장점은 일일이 언 급할 수 없을 정도로 많다. 또한 이 연구에서 졸업생들과의 면 담을 통해 이러한 장점을 다시 한번 확인할 수 있었다.

앞으로의 발전 방향에 대해서 비즈니스 측면의 발전 방향이 나 재활서비스로써 제도적인 장치, 전반적인 사회인식 개선, 공 식적인 검사의 수정, 워크샵이나 보수교육을 통한 지속적인 교 육 등을 언급하였다. 선후배 간의 교류를 통해 좀 더 유대적인 관계 형성을 원했고 후배들의 전문적인 교육 강화나 인성 교육 을 강화시킬 방안을 제안하였다. 전문가로서 현장에서 일해보 니 더 세부적인 전문 분야로 공부를 지속할 필요성을 느낀다는 의견이 많았고 그 외에 같은 직종이나 다른 직종 전문가와의 협력을 통해 다른 사람들과 교류하면서 협력하고 정보를 공유 하는 것이 중요하다고 하였다. 임상에서 대상자와 보호자 및 다른 전문가와 의사소통을 할 기회가 많기 때문에 전공 지식이 나 실습 이외에 상호작용 기술이 많이 필요하다고 하였다. 졸업 생들은 언어치료와 청각재활 전문가로서 발전을 위해 모두 지 속적이고 전문적인 교육이 필요하다고 하였다. 선행 연구들에 서도 국내 언어재활사들뿐만 아니라 외국 언어재활사들도 교육 과 슈퍼비전을 통해 전문적 역량을 강화시키기를 원하며 상담 기술을 비롯한 의사소통 전략을 향상시키고자 하는 것으로 나 타났다(Han \& Lee, 2015; Kim \& Park, 2018; Meibos et al., 2016; Park et al., 2016). 현재 국내에서 많은 언어재활사와 청능 사들이 졸업 후 임상에서 슈퍼비전을 받거나 지속적인 교육을 받고자 하는 욕구는 강하게 느끼고 있으나 시간적, 경제적, 제 도적 여건 등을 이유로 교육이 제대로 이루어지지 않고 있다. 이를 위해 협회 차원에서의 제도적 마련과 함께 교육기관에서 졸업생들을 중심으로 지역 사회에 있는 언어재활사와 청능사를 대상으로 전문적인 재교육의 장을 제공할 필요가 있다. 또한, 청 각장애 인구가 늘어나면서 인공와우 수술 후 청력을 회복하기 위해서는 매핑과 언어치료의 중요성이 강조되고 있다(Park et al., 2020). 따라서 청각장애언어치료 분야에서도 현장에 필요한 특화된 전문가 양성을 통해 양질의 재활 서비스를 제공하기 위 해 노력하는 것이 필요하다(Park et al., 2020).
본 연구를 통해 언어치료나 청각재활을 전공하고 임상에서 일하고 있는 졸업생들의 근무 현황 및 직업의 만족 정도, 전공 과 직무의 연관성, 앞으로의 발전 방향에 대해 이해할 수 있었 다. 언어재활사와 청능사는 근무의 자율성과 업무의 전문성을 가진 특수 전문직으로 다양한 근무기관에서 임상경험을 쌓아 지속적으로 자기 개발을 할 수 있을뿐만 아니라 개업 등을 통 해 새로운 패러다임을 구축해나갈 수 있는, 전문 자격을 가진 미래지향적인 직종인 것을 알 수 있었다. 이러한 기초 연구를 바탕으로 언어치료와 청각재활 분야의 현 주소를 확인하고 직 무적인 과제뿐만 아니라 대학의 교육과정이 당면하고 있는 문 제를 분석하고 대처방안을 모색해보았다.

본 연구의 제한점은 특정 대학의 졸업생만을 대상으로 하여 여러 대학 전공자, 단일전공자의 경험을 비교하여 살펴보지 못 한 점과 소수의 현장경험이라 확대해석하는 데는 주의가 요구 된다. 이러한 제한점을 가지고 있지만, 질적 연구의 특성상 두 가지 전공자의 깊은 현장경험을 전달하고자 하였다.

중심 단어 : 청각재활·임상 현장 경험·직무만족도·질적연구· 언어치료.

\section{Ethical Statement}

In this study, the experiment was carried out based on the consent of the subject after being deliberated by the Woosong University Institutional Bioethics Committee (IRB: 1041549-200407-SB-93).

\section{Acknowledgments}

N/A

\section{Declaration of Conflicting Interests}

There are no conflict of interests.

\section{Funding}

This research was conducted by the 2020 Woosong University inschool academic research grant fund support.

\section{Author Contributions}

P.T. designed and performed experiments, analyzed data, and wrote the paper; S.L. and P.T. designed and performed experiments in the clinic; J.K. and S.L. provided statistical analysis and critical revision; J.K. designed experiments, analyzed data, and wrote the paper. Also, the authors discussed the results together and implications and commented on the manuscript at each stage.

\section{ORCID iDs}

Ji Youn Kim https://orcid.org/0000-0003-4259-7784

Pyung Kon Thak https://orcid.org/0000-0001-7498-7328

\section{REFERENCES}

Brännström, K. J., Holm, L., Larsson, J., Lood, S., Notsten, M., \& Turunen Taheri, S. (2016). Occupational stress among Swedish audiologists in clinical practice: Reasons for being stressed. International Journal of $A u$ diology, 55(8), 447-453.

Chang, S. A., Kim, H. J., Kim, H. H., Choi, S. H., Hwang, B. M., Park, H. J., 
et al. (2018). Job searching and postings for speech language pathologists in Korea. Communication Sciences and Disorders, 23(2), 506-518.

Chang, S. A. \& Park, H. Y. (2012). A study on job commencement, change of employer, and job satisfaction of speech language therapists. Journal of Speech and Hearing Disorders, 21(4), 265-286.

Han, Y. J. \& Lee, S. A. (2015). Needs analysis of supervision for speech language pathologists: Focusing on the degree of demand on education content, burn-out and job satisfaction. Journal of Speech-Language and Hearing Disorders, 24(3), 149-160.

Hwang, H. J., Park, J. W., Choi, S. Y., Kim, S. H., \& Kim, S. H. (2015). A study of the relationship between job stress and burnout among speech and language pathologists. Journal of Speech-Language and Hearing Disorders, 24(4), 215-224.

Jang, H., Cho, S. J., Lim, D., \& Cho, S. H. (2007). The role of audiologists in educational settings-audiologic services. Audiology, 3(1), 1-8.

Kalkhoff, N. L. \& Collins, D. R. (2012). Speech-language pathologist job satisfaction in school versus medical settings. Language, Speech, and Hearing Services in Schools, 43(2), 164-175.

Kim, J., Choi, S. H., Kim, H. H., Chang, S. A., Kim, H. J., Hwang, B. M., et al. (2018). A nationwide survey on clinical curricula and practica in speech-language pathology educational programs in Korea. Communication Sciences and Disorders, 23(3), 807-828.

Kim, T. W. \& Park, Y. S. (2018). A study on the stress and skepticism of speech-language pathologist. Journal of Speech and Hearing Disorders,
27(3), 203-214.

Krippendorff, K. (2003). Content Analysis: An Introduction to Its Methodology. (2nd ed.), (pp. 150-155). Thousand Oaks, CA: Sage publications, Inc.

Lee, J. E. \& Hwang, S. S. (2013). A study on job satisfaction and turnover intention in speech-language pathologists. Journal of Speech-Language and Hearing Disorders, 22(3), 231-254.

Martin, F. N., Champlin, C. A., \& Streetman, P. S. (1997). Audiologists' professional satisfaction. Journal of the American Academy of Audiology, 8(1), 11-17.

Meibos, A., Muñoz, K., White, K., Preston, E., Pitt, C., \& Twohig, M. (2016). Audiologist practices: Parent hearing aid education and support. Journal of the American Academy of Audiology, 27(4), 324-332.

Park, E., Thak, P. K., \& Im, G. J. (2020). Cochlear implantation in adults. The New England Journal of Medicine, 383(5), e33.

Park, S. H., Park, H. Z., \& Chun, S. Y. (2016). Work-related difficulties experienced by novice speech-language pathologists. Special Education Research, 15(3), 203-226.

Saccone, P. \& Steiger, J. (2012). Audiologists' professional satisfaction. American Journal of Audiology, 21(2), 140-148.

Severn, M. S., Searchfield, G. D., \& Huggard, P. (2012). Occupational stress amongst audiologists: Compassion satisfaction, compassion fatigue, and burnout. International Journal of Audiology, 51(1), 3-9. 


\section{APPENDIX}

\section{졸업생 대상 질문 내용}

\begin{tabular}{|c|c|}
\hline 업무 역량 & $\begin{array}{l}\text { 지금 하고 있는 업무에 대해 소개해주세요 } \\
\text { 재직 중인 직장, 직장문화에 대해 이야기해주세요. } \\
\text { 일하면서 좋은 점에 대해 이야기해주세요. } \\
\text { 일하면서 어려운 점에 대해 이야기해주세요. } \\
\text { 업무에 필요한 능력은 무엇이라 생각하는지요? } \\
\text { 자신만의 노하우가 무엇인지요? }\end{array}$ \\
\hline 전공 관련성 & $\begin{array}{l}\text { 자신의 전공 만족도에 대해서 이야기해주세요. } \\
\text { 복수전공에 대한 의견을 제시해주세요. } \\
\text { 직장 선택시 가장 중요하게 생각한 것은 무엇인가요? 예) 연봉, 복지, 지역, 발전성 등. } \\
\text { 학교에서 공부한 전공 공부가 현재 업무에 얼마나 영향을 주는지 이야기해주세요. } \\
\text { 학교에서 공부한 내용 중 보완되면 좋은 점에 대해 이야기해주세요. } \\
\text { 학과 교수님들에게 바라는 점에 대해 이야기해주세요. } \\
\text { 후배들에게 해주고 싶은 말에 대해 이야기해주세요. } \\
\text { 학교에 바라는 점에 대해 이야기해주세요. }\end{array}$ \\
\hline 미래 전망성 & $\begin{array}{l}\text { 현재 업무에서 발전 방향에 대해 말해주세요. } \\
\text { 미래를 위해 준비할 사항에 대해 말해주세요. } \\
\text { 학과, 학교의 발전 방향에 대해 말해주세요. }\end{array}$ \\
\hline
\end{tabular}

